\title{
Preschool Teachers' Practices in English Early Literacy Instruction: A Case Study
}

\author{
Farah Munirah Roslan Johari, Faridah Yunus* \\ Faculty of Education, Universiti Kebangsaan Malaysia, Bandar BaruBangi, Malaysia \\ Email: farahmunirahroslanjohari92@gmail.com, ${ }^{\star}$ faridahyunus@ukm.edu.my
}

How to cite this paper: Roslan Johari, F. M., \& Yunus, F. (2019). Preschool Teachers' Practices in English Early Literacy Instruction: A Case Study. Creative Education, 10, 2701-2710.

https://doi.org/10.4236/ce.2019.1012196

Received: October 16, 2019

Accepted: November 25, 2019

Published: November 28, 2019

Copyright $\odot 2019$ by author(s) and Scientific Research Publishing Inc. This work is licensed under the Creative Commons Attribution International License (CC BY 4.0).

http://creativecommons.org/licenses/by/4.0/ (c) (i) Open Access

\begin{abstract}
This case study aims to address preschool teachers' practices in early literacy instruction specifically, the literacy skills focused by teachers during English early literacy classroom instruction. Four in-service teachers from three types of preschool which are government, private and non-government organization located in a suburban area, were involved as the study's participants. Data collection involved were checklist, field notes, video recording, and classroom observations. A checklist of literacy is an instrument used to analyze literacy skills practice by teachers. Results show that there is a lack of focus given on certain areas of literacy skills which are: 1) auditory discrimination, 2) visual discrimination, 3) phonological awareness, 4) phonemic awareness, and 5) reading as practiced by those teachers. Generalization may not be fair at this stage but the findings could reflect the need to (re)train teachers. Larger samples are crucial to understand the scale of the teaching practice being inappropriate, hence, help in the development of training module that would result in more literacy skills being practiced during English language teaching and learning.
\end{abstract}

\section{Keywords}

Early Literacy Instruction, Literacy Skills, Preschool

\section{Introduction}

The Malaysian government's awareness of the importance of teaching early literacy is clearly illustrated in the Malaysia Education Blueprint 2013-2025 whereby enhancing the proficiency of both the Malay and English language of all students is of priority and every child will acquire basic literacy skills in both Malay and English language after three years of schooling. In an effort to achieve this, the government launched an intervention programme called the Kelas Intervensi 
Awal Membaca dan Menulis (Reading and Writing Early Intervension) in 2006 and was subsequently replaced with the LINUS (Literacy and Numeracy Screening) program beginning in 2010. However, these two programmes were only focusing on the Malay Language. In 2013, it was later changed to LINUS 2.0 which included both the Malay and English language.

Although such efforts are commendable, these programs were only focused on children entering primary school at the age of seven. It was not focused on children in preschools. However, the LINUS 2.0 was recently abolished in 2019 and it was announced that there will be no examinations for primary school students from Year 1 until Year 3. It was also announced that schools shall implement their own programmes to address students' problems in mastering basic numeracy and literacy skills. This suggests that children's literacy skills should be more focused on when they are in preschools. Literacy should start at an earlier age before entering primary school. In fact, early literacy development starts from birth until the child enters school (Wildová \& Kropáčková, 2015). Therefore, it is critical for preschool teachers to ensure that children receive enriched literacy experience. Teachers play a significant role in children's early literacy development in which they have the ability to influence children's development in literacy skills (Dennis \& Horn, 2011). Studies have shown that teachers implement poor instructional practices in English early literacy teaching and learning (Asmawi \& SyedHendi, 2016, 2018). Moreover, studies on English early literacy instruction in the Malaysian preschool setting are limited. Therefore, this paper aims to investigate early literacy instruction based on the following research questions:

1) What are the early literacy skills focused by teachers during classroom instruction?

2) What are teacher's early literacy instructional practices during classroom instruction?

\section{Literature Review}

Early literacy skills are an important foundation for children's learning and education. It is critical to introduce early literacy learning at an early age. If children's interest in literacy learning can be inculcated from when they were introduced to print, it can help increase their confidence in literacy learning and promote successful learning (Fern \& Jiar, 2014). Moreover, children who are exposed to literacy learning at an early are likely to excel in school compared to children who started late. Children who could not read or write before entering primary school may experience difficulties in learning later on. However, early exposure to literacy would be deemed meaningless if children's early literacy instruction were insufficient. Therefore, it is imperative that children receive an effective early literacy instruction and learning.

Preschool teachers play a critical role in shaping and developing children's early literacy. It is important that teachers provide children with enriched literacy experience and sufficient literacy instruction and practices. The way teachers 
implement instructional practices have a significant influence on children's literacy development. It may impact children either positively or negatively depending on how the teacher executes classroom instructions. Children who experienced enriched literacy experiences are more likely to succeed compared to children who did not. Majzub (2013) mentioned that children's development and learning are influenced by their experienced be it positive or negative which will have an impact on them for a long time.

In regards to early literacy instruction, Paciga, Hoffman, and Teale (2011) are concerned that there is a potential, skill-and-drill activities that focus on memorization may replace richer learning activities. Activities that are emphasized on memorization and rote learning will only provide less opportunities for children to practice literacy learning because literacy requires interaction which rote learning does not. Also, such activities will attract little attention and interest from the children. Baroody and Diamond (2016) mentioned that when children are interested and engaged during early literacy activities they are more likely to have "more opportunities to learn and practice early reading skills" (p. 147). Children who have poor literacy skills does not mean that they are not able to learn. However, it is because they were not engaged during classroom activities (Abdul Rahman \& Maaarof, 2015). Therefore, in order to attract children's attention during classroom instruction, teachers should be both creative and innovative (Misbah et al., 2017).

In regards to early literacy instruction, Pray (2010) believes that most of the local English language teachers do not have much experience teaching English language learners as well as learning a second language. This suggests that most local teachers teach English when in fact, they themselves have little knowledge and experience regarding the subject. Furthermore, Tang et al. (2011) revealed in their study that most preschools in Malaysia are not required to employ teachers "who meet even the most basic professional requirements" (p. 98). This suggests that most preschool teachers in Malaysia does not need even the most basic professional qualification to teach in preschools. Therefore, it is critical to ensure that preschool teachers are developed and equipped professionally in early childhood education as well as in early literacy instruction. Moreover, beginner teachers with little experience should also be given proper training before teaching. Similarly, Md. Yunus et al. (2010) mentioned that it is essential for beginner teachers to be given quality training.

\section{Methodology}

Purposive sampling was used as a sampling method in the present study. Three types of preschools were selected as the research sites for the present study which are a government, private and a non-government organization. The selection of three preschools was based on three factors. First, the preschools are of three different types of kindergarten. Second, the preschools' curriculum is subject-based. Third, the preschools are located in a suburban area. 
Four in-service preschool teachers from the three preschools were selected to participate in the study. Teacher A teaches in a private preschool and has been involved in the field of early childhood education for about 20 years. Teacher B teaches in a government preschool and has been serving for three years. Teacher $\mathrm{C}$ teaches in an NGO preschool and has been teaching in the present preschool for less than a year. Teacher D is also teaching in a non-government organization preschool and has been teaching in the present preschool for less than six months.

Classroom observations were conducted for all three preschools. Each teacher was observed during their English lessons and the observations were video-recorded. The researcher also took field notes of each observation session and took pictures of the materials used during the lessons. The purpose of the field notes was to record and collect important data that reflects teachers' classroom instruction practices. A checklist adapted from a reading and writing checklist by (Fyke, 2007) was used. The checklist consists of seven sections which are print concepts, auditory discrimination, visual discrimination, phonological awareness, phonemic awareness, reading and writing. After reviewing teachers' practices based on the field notes and video records from observations, the researcher checked the items from the checklist accordingly. The checklists were checked based on whether or not the skills were implemented or demonstrated by the teacher or children during the lessons.

\section{Results}

Table 1 displays print concepts skills focused by the four teachers throughout the observation sessions. The results show that most of the teachers do implement most print concept skills in their lessons.

Table 2 shows the auditory and visual discrimination skills focused by the

Table 1. Print concepts skills focused by teachers.

\begin{tabular}{|c|c|c|c|c|}
\hline \multirow{2}{*}{ Skills } & \multicolumn{4}{|c|}{ Teacher } \\
\hline & A & B & $\mathrm{C}$ & $\mathrm{D}$ \\
\hline Demonstrate knowledge of book orientation. & $\mathrm{x}$ & $\mathrm{x}$ & $\mathrm{x}$ & $\mathrm{x}$ \\
\hline \multicolumn{5}{|l|}{ Develops prediction. } \\
\hline Demonstrate knowledge that print carries meaning. & $\mathrm{x}$ & $\mathrm{x}$ & & $\mathrm{x}$ \\
\hline Demonstrate knowledge of left-to-right and top-to-bottom directionality. & $\mathrm{x}$ & $\mathrm{x}$ & $\mathrm{x}$ & $\mathrm{x}$ \\
\hline $\begin{array}{l}\text { Demonstrate knowledge of word-by-word matching and left-to-right } \\
\text { movement across the page. }\end{array}$ & $\mathrm{x}$ & $\mathrm{x}$ & & \\
\hline Demonstrate knowledge of movement to the next page. & & $\mathrm{x}$ & $\mathrm{x}$ & $\mathrm{x}$ \\
\hline Demonstrate knowledge of-left-to-right return sweep. & $\mathrm{x}$ & & & \\
\hline Discriminate between letter and word. & $\mathrm{x}$ & $\mathrm{x}$ & & $\mathrm{x}$ \\
\hline \multicolumn{5}{|l|}{ Demonstrate knowledge of voice-to-print matching. } \\
\hline Demonstrate knowledge of punctuation marks. & & & & \\
\hline
\end{tabular}


Table 2. Auditory discrimination and visual discrimination skills focused by teachers.

\begin{tabular}{|c|c|c|c|c|c|}
\hline \multirow{2}{*}{ Category } & \multirow{2}{*}{ Skills } & \multicolumn{4}{|c|}{ Teacher } \\
\hline & & A & B & $\mathrm{C}$ & $\mathrm{D}$ \\
\hline Auditory Discrimination & Identify environmental sounds. & & & & \\
\hline \multirow[t]{5}{*}{ Visual Discrimination } & Sort words by visual cues. & & & & \\
\hline & $\begin{array}{l}\text { Discriminate between words that } \\
\text { are the same or different. }\end{array}$ & & & & \\
\hline & Identify his or her first name out of unfamiliar names. & & & & \\
\hline & Identify his or her first name out of classmates' names. & & & & \\
\hline & Determine which of letters is unlike the others. & & & $\mathrm{x}$ & \\
\hline
\end{tabular}

teachers. Results show that there was no focus given to auditory discrimination skills. Little or no focus was given by most of the teachers on visual discrimination skills. Only one teacher did implement one of the skills in the classroom, however, she did not directly demonstrate the skill to the children but she instructed the children to do a worksheet which requires them to determine like and unlike letters.

Table 3 displays the phonological awareness skills focused by the teachers. Based on the observations, all four teachers only focused on identifying and recognizing letters. Teachers did not draw children's attention to other phonological awareness skills.

Table 3. Phonological awareness skills focused by teachers.

\begin{tabular}{|c|c|c|c|c|}
\hline \multirow{2}{*}{ Skills } & \multicolumn{4}{|c|}{ Teacher } \\
\hline & A & B & $\mathrm{C}$ & $\mathrm{D}$ \\
\hline \multicolumn{5}{|c|}{ Clap and count the number of syllables in a given word. } \\
\hline \multicolumn{5}{|l|}{ Segment sentences into words. } \\
\hline \multicolumn{5}{|l|}{ Identify a rhyme. } \\
\hline \multicolumn{5}{|l|}{ Produce rhyming words. } \\
\hline \multicolumn{5}{|l|}{ Blend onsets and rimes } \\
\hline Identify upper-and lowercase letters. & $\mathrm{x}$ & $\mathrm{x}$ & $\mathrm{x}$ & $\mathrm{x}$ \\
\hline
\end{tabular}

Table 4 shows the phonemic awareness skills focused by the four teachers observed. Based on observations, rarely did the researcher see teachers draw attention to the sounds of letters. Most of the time, more emphasis was put on identifying and recognizing letters.

Table 5 displays the reading skills focused by the teachers during classroom instruction. Results show that little focus was given to children's reading skills. Teachers did not draw children's attention to most of the skills. They only emphasized on reading aloud during lessons where teachers read aloud while pointing to a sentence or a word and children repeat after the teacher loudly. 
Table 4. Phonemic awareness skills focused by teachers.

\begin{tabular}{|c|c|c|c|c|}
\hline \multirow{2}{*}{ Skills } & \multicolumn{4}{|c|}{ Teacher } \\
\hline & A & B & $\mathrm{C}$ & $\mathrm{D}$ \\
\hline Recognize and say the sounds of uppercase and lowercase letters. & $\mathrm{x}$ & $\mathrm{x}$ & & \\
\hline Identify the sounds of digraphs. & & & & \\
\hline Identify the beginning, middle, and ending sound of words. & & & & \\
\hline Match words that begin or end with the same sound. & & & & \\
\hline Blend phonemes together to read VC, CV, VCC, and CVC words. & & & & \\
\hline $\begin{array}{l}\text { Blend phonemes together to read CCVC, CVCC, CVVC, CCVVC, } \\
\text { and more words. }\end{array}$ & & & & \\
\hline Segment words into phonemes & & & & \\
\hline
\end{tabular}

Table 5. Reading skills focused by teachers.

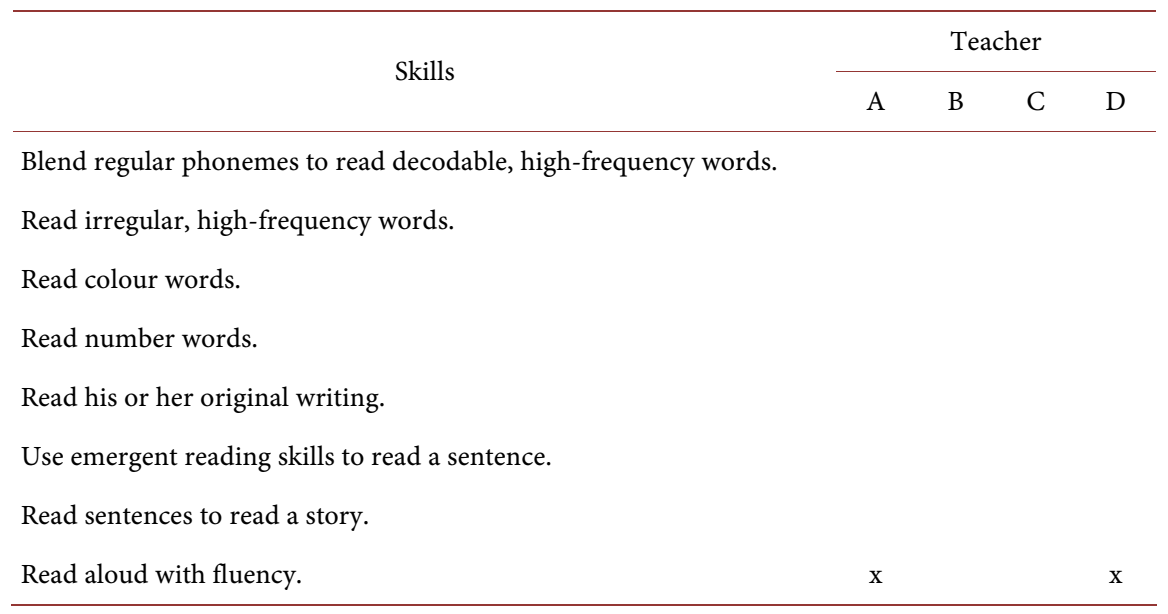

Table 6 shows the writing skills focused by teachers during classroom instruction. Based on classroom observations, only basic writing skills were implemented such as demonstrating an established hand preference, demonstrating a correct pencil grip, printing lowercase letters of the alphabet and writing or copying words.

Table 6. Writing skills focused by teachers.

\begin{tabular}{llllll} 
Skills & \multicolumn{4}{c}{ Teacher } \\
\cline { 2 - 6 } & & A & B & C & D
\end{tabular}

Draw a self-portrait.

Demonstrates organizational skills using arrangement of picture details, text, and position on page.

Demonstrate an established hand preference.

Demonstrate a correct pencil grip.

Print lowercase letters of the alphabet.

Print uppercase letters of the alphabet.

$\begin{array}{cccc}\mathrm{x} & \mathrm{x} & \mathrm{x} & \mathrm{x} \\ \mathrm{x} & \mathrm{x} & \mathrm{x} & \mathrm{x} \\ \mathrm{x} & \mathrm{x} & \mathrm{x} & \mathrm{x} \\ & \mathrm{x} & & \end{array}$




\section{Continued}

Print his or her first name legibly.

Print his or her last name legibly.

Use knowledge of letters to write or copy words legibly.

Copy words from environmental print, writing from left to right.

$\mathrm{x}$

Copy sentences text from a printed page, writing from left to right.

Write teacher-dictated decoded words by segmenting practiced sounds and connecting the phoneme to the grapheme(s).

Spell teacher-dictated irregular, high-frequency kindergarten words, using conventional spelling.

Contribute ideas during an interactive activities.

Write words on a chart during an interactive writing activity.

Express ideas by describing pictures, dictating, drawing, or storytelling.

Use emergent forms of writing to record ideas.

Write using an assortment of tools

Demonstrate developing knowledge of print conventions.

Perform writing in a variety of formats.

Perform writing in a variety of genres.

\section{Discussion}

In this study, teachers' English literacy instructional practices are reflected in the skills content implemented by teachers during classroom instruction. The findings show that there is a lack of attention given to certain areas of literacy skills such as auditory discrimination, visual discrimination, phonological awareness, phonemic awareness and reading.

During observations, a lot of emphases were put on recognizing letters of the alphabet but little focus was given to the sounds of letters. Out of the four teachers only two teachers did somewhat draw children's attention to the sounds of letters, however, they did not focus on other phonemic awareness skills. The teachers did not ensure children demonstrate awareness that different words may begin with the same sounds (alliteration) or draw children's attention to rhythmic patterns in words (rhyme). Pullen and Justice (2003) emphasized that "both rhyme and alliteration reflect children's ability to focus sub-lexically on the phonological structure of spoken language, that is, to consider the sound structure of language as separate from meaning" (p. 90). Similarly, in a study conducted by Asmawi and SeyedHendi (2016), it is reported that teachers seldom focus on alliteration and rhyme.

Despite the fact that visual skills are required for visual word reading (Zhou et al., 2014), most of the teachers did not focus on visual discrimination skills. Visual discrimination skills are essential in recognizing and differentiate letters. Children with poor visual discrimination skills will have difficulty identifying, recognizing and discriminating between letters and words (Weveti, 2017). If a 
child cannot discriminate or identify the difference and similarities between different letters and words, he or she will experience difficulty in learning how to read and write. Therefore, "early intervention in kindergarten is exponentially more successful than later remediation” (Fern \& Jiar, 2014: p. 145).

Based on observation, most of the teachers only implemented basic writing skills during classroom instruction such as writing letters and copying words. Writing activities usually involved pencil-and-paper activities and were not very interactive. Genlott and Grönlu (2013) mentioned that writing is a "culturally defined social activity" (p. 99). This suggests that writing is an interactive social skill because it involves conveying messages to others. Therefore, writing activities should involve interacting and communicating with others. Furthermore, based on classroom observations, teachers did not encourage children to contribute and communicate ideas during these activities. They did not encourage children to be creative and express themselves. Writing requires learners to express their ideas and put them into words and sentences (Abdul Aziz \& Lawai, 2019). Writing activities do not necessarily have to be constricted to only pencil-and-paper activities. It may also involve children expressing ideas creatively by telling stories and drawing pictures.

Despite the fact that reading skills are probably one of the most essential literacy skills to acquire, based on observations, it seems that little focus was given to reading skills during classroom instruction. The only skill that was implemented was reading aloud whereby teachers instructed children to read aloud by repeating the teacher as the teacher points to each word and read it loudly. Teachers did not draw children's attention to blending sounds to read words. Teacher are more focused on whole-word reading rather than learning to read words by blending sounds. Although whole-word reading may be effective in increasing the number of words that children can recognize, it does not teach children strategies which will enable them to work out by themselves on how to read words that are new and unfamiliar to them (Burgoyne et al., 2013).

\section{Conclusion}

All children should receive effective English literacy instruction for efficient and enriched literacy learning experience. It is important to begin English literacy learning at an early age. Early exposure to English literacy is exponentially more successful than introducing it to children at a later age. However, it is critical to note that early exposure would be meaningless if the practices of the English literacy instruction itself are inefficient. If preschool teachers were to implement poor English literacy instruction practices, children's English literacy development will be negatively affected in later years. Therefore, it is imperative to ensure that preschool teachers are practicing appropriate and sufficient English literacy classroom instruction. In conclusion, a competent preschool teacher should be equipped with knowledge and understanding of English literacy instruction. With proper training, preschool teachers can improve English literacy instruction. 


\section{Acknowledgements}

This research was supported by Universiti Kebangasaan Malaysia (National University of Malaysia) PP-FPEND-2019 and the project team of dcp-2017-020/3.

\section{Conflicts of Interest}

The authors declare no conflicts of interest regarding the publication of this paper.

\section{References}

Abdul Aziz, A., \& Lawai, S. (2019). Clustering Technique to Improve Rural Malaysian Primary School Pupil's Writing Skill. International Journal of New Technology and Research, 5, 13-17. https://doi.org/10.31871/IJNTR.5.7.30

Abdul Rahman, N. A., \& Maarof, N. (2015). The Relationship between Language Strategies and Students' Motivation in Learning English as a Second Language. Jurnal Terbuka Social Sains.

Asmawi, A., \& Seyed Hendi, N. (2016). Preschool English Teachers' Practices and Early Literacy Instruction: A Multiple Case Study. Asian Education Studies, 1, 1-3. https://doi.org/10.20849/aes.v1i2.72

Asmawi, A., \& Seyed Hendi, N. (2018). Preschool English Teachers' Practices and Early Literacy Instruction: Montessori vs International Preschool Curriculum. Malaysian Online Journal of Educational Sciences, 6, 29-36.

Baroody, A. E., \& Diamond, K. E. (2016). Associations among Preschool Children's Classroom Literacy Environment, Interest and Engagement in Literacy Activities, and Early Reading Skills. Journal of Early Childhood Research, 14, 146-162.

Burgoyne, K., Duff, F., Snowling, M., Buckley, S., \& Hulme, C. (2013). Training Phoneme Blending Skills in Children with Down Syndrome. Child Language Teaching and Therapy, 29, 273-290. https://doi.org/10.1177/0265659012474674

Dennis, L. R., \& Horn, E. (2011). Strategies for Supporting Early Literacy Development. Young Exceptional Children, 14, 29-40.

Fern, N. P., \& Jiar, Y. K. (2014). Preschool Teachers' Beliefs and Practices on Early Literacy Instruction. Sains Humanika, 2, 139-146.

Fyke, L. B. (2007). Essential Kindergarten Assessments for Reading, Writing, and Math. New York: Scholastic Inc.

Genlott, A. A., \& Grönlu, A. (2013). Improving Literacy Skills through Learning Reading by Writing: The iWTR Method Presented and Tested. Computer \& Education, 67, 98-104. https://doi.org/10.1016/j.compedu.2013.03.007

Majzub, R. M. (2013). Critical Issues in Preschool Education in Malaysia. Proceedings of the 4th International Conference of Education and Educational Technologies (pp. 150-155). Cambridge, MA.

Md Yunus, M., Hashim, H., Ishak, N. M., \& Mahamod, Z. (2010). Understanding TESL Pre-Service Teachers' Teaching Experience and Challenges via Post-Practicum Reflection Forms. Procedia Social and Behavioral Sciences, 9, 722-728.

https://doi.org/10.1016/j.sbspro.2010.12.224

Misbah, N. H., Mohamad, M., Md Yunus, M., \& Ya'acob, A. (2017). Identifying the Factors Contributing to Students' Difficulties in the English Language Learning. Creative Education, 8, 1999-2008. https://doi.org/10.4236/ce.2017.813136 
Paciga, K. A., Hoffman, J. L., \& Teale, W. H. (2011). The National Early Literacy Panel and Preschool Literacy Instruction: Green Lights, Caution Lights and Red Lights. Young Children, 66, 50-57.

Pray, L. (2010). ESL Teacher Education abroad and at Home: A Cautionary Tal. The Teacher Educator, 45, 216-229.

Pullen, P. C., \& Justice, L. M. (2003). Enhancing Phonological Awareness, Print Awareness and Oral Language Skills in Preschool Children. Intervention in School and Clinic, 39, 87-98. https://doi.org/10.1177/10534512030390020401

Tang, K. N., Hashim, N. H., \& Yunus, H. M. (2011). Preschool Teachers' Quality in Lesson Preparation and Implementation. The International Journal of Learning, 17, 89-105.

Weveti, M. J. (2017). Influence of Teacher Characteristics on Preschool Children Performance in Visual Discrimination of Words in English in Kaizuri Zone, Embu, Kenya. Kenya: University of Nairobi.

Wildová, R., \& Kropáčková, J. (2015). Early Childhood Pre-Reading Literacy Development. Procedia Social and Behavioral Sciences, 191, 878-883.

https://doi.org/10.1016/j.sbspro.2015.04.418

Zhou, Y., McBride-Chang, C., \& Wong, N. (2014). What Is the Role of Visual Skills in Learning to Read? Frontiers in Psychology, 5, 1-3.

https://doi.org/10.3389/fpsyg.2014.00776 